\title{
Disaggregating species unit costs in mixed fisheries: the case of the Irish whitefish fleet
}

\author{
Richard Curtin* \\ Economics and Strategic Services Unit, Bord Iascaigh Mhara, Crofton Road, Dun Laoghaire, Co. Dublin, Ireland
}

Received 16 November 2020 / Accepted 3 May 2021

Handling Editor: Dr. Olivier Thebaud

\begin{abstract}
Many fishing fleets operate in mixed fisheries where several target species are caught together along with other bycatch species unintentionally caught. In some cases, fleets operate in multiple mixed fisheries depending on various factors such as time of year or current market conditions, among other factors. Data collection in the European Union (EU) involves various levels of detailed data. Economic data is generally collected on an annual time-step whereas other sources provide information at much higher resolution such as the fishing trip (landings declarations), fish day (logbook) or even in real-time (electronic logbook). In this paper a methodology is described to disaggregate the annual cost of a fleet segment into a cost per fishery and per species within the fishery. This information is of interest as it permits incorporation of the economic implications of fishery dynamics into fisheries management. Assessment of these unit costs on a fishery basis also allows accurate input into value chain analysis which is carried out on a species basis.
\end{abstract}

Keywords: Unit costs / disaggregation / mixed fisheries

\section{Introduction}

The objective of this study is to develop a methodology to estimate the total cost involved in landing one unit (e.g., $1 \mathrm{~kg}$ ) of a selected species of fish. This is of interest from a fleet management perspective as the result can be used to assess the economic performance of fishing fleet operations when used in combination with the price. In general, a unit cost per species of below the unit price of said species shows that there is, at a minimum, normal marginal profits being generated by the fleet in capturing this fish. Depending on the variety of fishing fleet segments ${ }^{1}$ capturing a species the unit cost for each may vary, along with the unit price and so the difference in profit or loss margins can indicate which segments are the most efficient or profitable in capturing said species. Therefore, from a manager's perspective, knowledge of unit costs of species between fisheries may assist in the allocation of valuable quota at the national level where certain fisheries could face the problem of early closures due to the presence of choke species. From a market perspective the unit cost of capturing a species is of interest in assessing the supply chain and assessing

\footnotetext{
*Corresponding author: richard. curtin@bim.ie

${ }^{1}$ Defined as a group of vessels with the same length class and predominant fishing gear during the year (Commission Decision (EC) No 949/2008).
}

potential opportunities for value added activity. Knowing the margin gained by the fishing sector compared to other sectors such as processors, wholesalers and retailers is of interest when assessing the supply chain. This has social consequences with regard to the distribution of benefits along the value chain and can reflect the power dynamics, for example between large retailers as price setters and fishers as price takers.

To estimate cost per unit of landings of a species first the total costs of the group of vessels landing the species must be assessed. The economic performance of EU fleets are estimated annually through the Data Collection Framework (DCF) by means of economic surveys of active fishers (Council of the European Union 2009; 2017). The results of these surveys carried out across EU member states' fishing fleets describe the cost breakdown by fleet segments ${ }^{2}$ across the EU and feed into the Annual Economic Report of EU fishing fleets each year ${ }^{3}$. These fleet segments are formulated based on the volume share of landings of each vessel by each fishing gear. For example, if over half of the volume of fish landed by a vessel was with the use of demersal trawls or seines then the vessel is classified as a 'DTS' (demersal trawl and seine) fleet segment. A fishery has been defined as a group of

\footnotetext{
${ }^{2}$ Defined under common criteria to allow comparability across EU fishing fleets.

${ }^{3}$ https://stecf.jrc.ec.europa.eu/reports/economic.
} 
vessel voyages targeting the same assemblage of species and/ or stocks, using similar gear, during the same area and within the same part of the year (Davie and Lordan, 2009). As many fleets are active in multiple fisheries, some of which are mixed, economic analysis has been focused on the fleet segment. This is understandable from the point of view of collection of data however it may be problematic as the results may hide unprofitable fisheries. In order to effectively measure the relative economic performance of alternative fishing fleet segments, according to the fisheries in which they operate, the annual costs estimated for the Annual Economic Report must be disaggregated to the level of cost per landed unit of the species in question.

Many studies have assessed economic performance of fishing fleets using indicators based on data from data collection systems such as the DCF. The problem of scaling occurs in the DCF due to the homogenous criteria applied across all member states (Simmonds et al., 2011). Scaling issues occur in areas such as small-scale fleet definition (Carvalho et al., 2011; Guyader et al., 2013), crew share remuneration (Guillen et al., 2015; Prellezo and Iriondo, 2016), profitability measurement (Boncoeur et al., 2000; Garza-Gil et al., 2011) among other areas. (Daurès et al., 2013) proposed a range of predictive models of operational costs to overcome a number of problems with the DCF economic programme such as difficulty in gathering survey data, incomplete coverage of fleets and inadequate coverage of fisheries. The cost structure models parameterised explain the drivers behind each cost aspect and in certain cases allow application to data deficient fleet segments. Garza-Gil et al. (2011) assessed the profitability of the Spanish purse seiner fleet after a structural change using bootstrap techniques. Boncoeur et al. (2000) propose an alternative measure of longterm profitability for small-scale fleets as the indicators in use were not detecting structural changes in fleets in the English Channel. Guillen et al. (2015) analyse how the crew share remuneration system affects rent distribution and fishing decisions.

In this paper an attempt is made to re-scale the DCF fleetbased data to the level of the fishery. DCF data collates economic data on EU fishing vessels and aggregates this into fleet segments. The methodology here will take into account the fisheries that a species occurs in and then allow estimation of the unit cost of landing said species (see Fig. 1 for a map of fishing grounds around Ireland). The methodology will be applied to two species of importance to the Irish seafood sector, hake and nephrops, for illustrative purposes. These species are selected as they are key target species for a number of fleet segments in Ireland and largely influence their economic performances. An interesting aspect of fisheries is that certain species can be caught in different fisheries and so the costs involved in landing different species can differ depending on the fisheries in which these species occur. For example, whiting can be caught in a targeted whiting fishery while it can also be caught as a bycatch species in a targeted fishery for another species such as nephrops. Hence, a unit cost of fishing each species is dependent on the fishery in which it is caught.

The fleets that target hake and nephrops and the relevant fisheries will be described in the background section. The methodology will then be described in the materials and methods section. Results will then be detailed followed by a discussion and conclusions.

\section{Background}

Hake and nephrops are landed mainly by the polyvalent general fleet, the largest segment of the Irish fleet with the most vessels, gross tonnage and vessel power. Irish national segmentation is more broadly defined than DCF segmentation ${ }^{4}$ and is based on the potential fisheries that a vessel can exploit ${ }^{5}$. The polyvalent general segment mostly use demersal trawls but can also use gillnets and other assorted gears. The segment lands a multitude of whitefish species (over 70) in varying quantities. The segment includes vessels that range from small inshore vessels below $10 \mathrm{~m}$ in length to offshore vessels above $30 \mathrm{~m}$ with the vessel length (VL) classes above $18 \mathrm{~m}$ accounting for the majority of landings of the main species. The three main targeted mixed fisheries that this segment exploits have been identified as the nephrops fishery ${ }^{6}$, the hake-monkfish-megrim fishery ${ }^{7}$ and the cod-haddock-whiting fishery ${ }^{8}$.

The nephrops (NEP) fishery in Ireland occurs across numerous functional units (fishing grounds) in the Irish Sea and in the Celtic Sea ${ }^{9}$. The vessels that exploit this fishery are mainly trawlers utilising nets with $70-80 \mathrm{~mm}$ mesh size codends. The fishing grounds, technical characteristics of the vessels and other factors determine the level of bycatch in this fishery which can include whiting, haddock, cod and other whitefish species.

The hake-monkfish-megrim (HMM) fishery generally occurs on a north-south line to the west of the island of Ireland corresponding to increasing water depths along the continental shelf of Ireland. Vessels exploiting this fishery are mainly trawlers utilising nets with 100-120 mm mesh size codends.

The cod-haddock-whiting (CHW) fishery occurs throughout the Celtic Sea by trawlers utilising nets with $100-120 \mathrm{~mm}$ mesh size codends.

In Figure 2 below the value of declared landings of hake and nephrops are shown for the main segments of the Irish fleet. It can be seen that the polyvalent general segments of

\footnotetext{
${ }^{4}$ DCF segmentation is determined by the volume of fish landed by the predominant gear. See https://datacollection.jrc.ec.europa.eu/wordef/ fleet-segment-dcf and Commission Implementing Decision (EU) 2016/1251 for further details.

${ }^{5}$ The main segments in Ireland are pelagic, beamer, specific, polyvalent general and aquaculture. The corresponding DCF segments are broadly pelagic trawl (TM), beam trawl (TBB), dredgers (DRB), demersal trawls and seines (DTS) respectively (excluding aquaculture). Further details can be found here; https:// www.gov.ie/en/organisation-information/5907a-sea-fisheries-admin istration/.

${ }^{6}$ Browne et al. (2017).

${ }^{7}$ Also known as benthic fisheries; ICES Fisheries Overviews; Celtic Seas Ecoregion (2020).

${ }^{8}$ Also known as gadoid fisheries; ICES Stock Annex: Celtic Sea Mixed Fisheries Annex (2015).

${ }^{9}$ Six functional units of nephrops are exploited by the Irish fleet namely FU 15-Irish Sea, FU 22-the Smalls, FU 20-21-Labadie, Jones and Cockburn, FU 19-Ireland SW and SE coast, FU 17-Aran, Galway Bay and Slyne Head, FU 19 Porcupine Bank. http://www. ices.dk/sites/pub/Publication\%20Reports/Advice/2018/2018/nep. fu.14.pdf.
} 


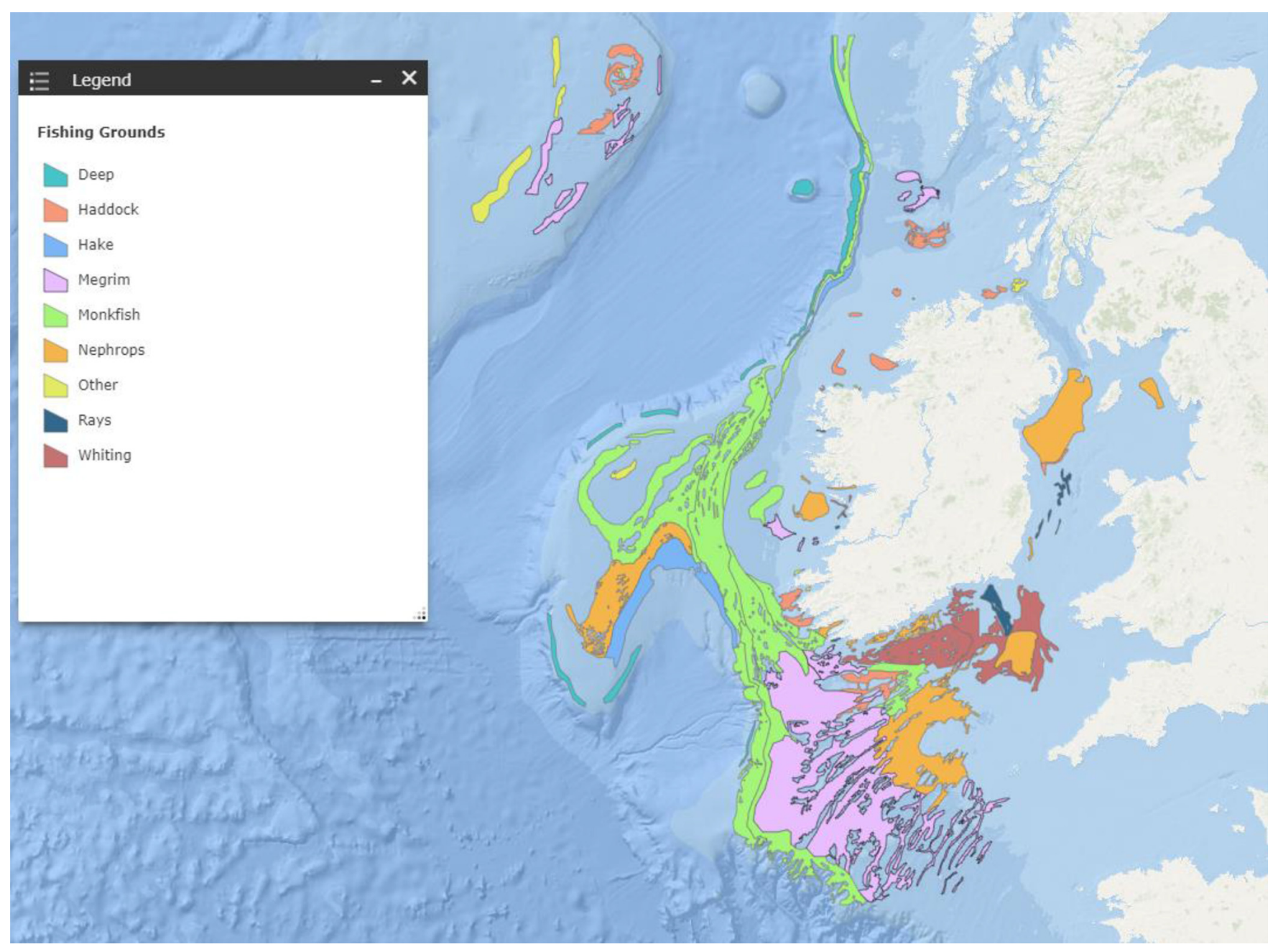

Fig. 1. Important fishing grounds around Ireland; source BIM Inshore Fishery GIS Viewer.

\section{Hake Value Shares by Segment}

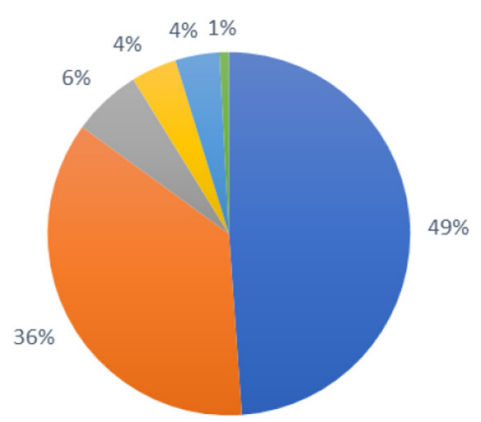

Nephrops Value Shares by Segment

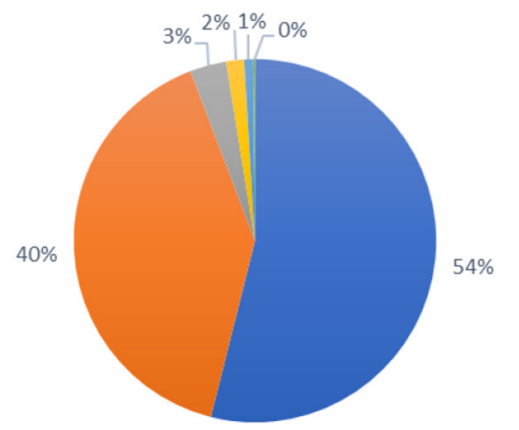

- Polyvalent General VL1824

匹 Polyvalent General VL2440

- Polyvalent General VL1518

ㅍ Polyvalent General VL1215

a Polyvalent General VL1012

- Others All

Fig. 2. Value shares of total Irish hake and nephrops landings by fleet segment in 2019 (see Tab. A.1 in Appendix).

VL1824 and VL2440 (hereafter grouped and labelled the 'whitefish fleet') account for $85 \%$ of the value generated from total Irish hake landings and $94 \%$ of the value of total Irish nephrops landings. Given this dominant position focus will be drawn upon the cost structure of the whitefish fleet to associate costs to these species.

\section{Materials and methods I: fishery allocation}

As mentioned previously the Irish whitefish fleet generally operates in the three main fisheries of CHW, HMM and NEP. Other fisheries are exploited by this fleet at certain times of the 
Table 1. Summary statistics for the whitefish fleet by fishery.

\begin{tabular}{llllll}
\hline & CHW & HMM & NEP & OTH & Total \\
\hline Effort (Days at Sea) & 2598 & 8374 & 11074 & 3760 & 25807 \\
Landings (Tonnes) & 5411951 & 9757407 & 7853700 & 34339555 & 57362614 \\
Revenue $(€)$ & 12404401 & 32150455 & 61994331 & 37247203 \\
Price $(€ / \mathrm{KG})$ & 2.29 & 3.29 & 7.89 & 1.08 & 143796390 \\
\hline
\end{tabular}

Fishery definition: (cod, haddock, whiting - CHW; hake, monkfish, megrim - HMM; nephrops - NEP; all others - OTH).

year such as the spring herring fishery, the mackerel fishery or the albacore fishery during the late summer months. Therefore, a fourth fishery encompassing these and any other fisheries will be assigned to the fleet (OTH).

Why a fisher makes a decision to enter a fishery is due to a number of reasons spanning their capabilities, the technical capacity of their vessel, regulatory constraints and the potential economic returns among other factors. From an economic perspective the potential economic returns from fishing something somewhere is the main driver affecting fishery choice and fisher behaviour. Fisheries where an operator can make a higher profit will be favoured and effort within that fishery should increase (Hilborn, 2007).

Part one of the methodology is to assess the activity of the fleet by fishery. Here this is done by analysis of detailed logbook data. Detailed data analysis at the level of the trip is required as summarised data at greater temporal scales (month, year) may include activity in various fisheries. EU logbooks ${ }^{10}$ are composed of a daily sheet recording the catch details (including volume, area and gear used) per day with a landings declarations sheet that is filled out at the end of the trip in the port summarising total landings per species and area (ICES sub-division) for the entire fishing trip ${ }^{11}$.

Analysis of logbook databases allows assessment at the level of the fishing day while analysis of landings declarations databases allows assessment at the level of the fishing trip. For the purposes of examining activity within fisheries, assessment of landings declarations is sufficient as the majority of fishing trips are expected to be in a distinct fishery rather than multiple fisheries being exploited within one fishing trip, given the length of time involved in rigging the distinct gear specifications on board the vessel across fisheries. The value of each species landed is incorporated into the landings declarations database through linkage with the sales notes database. Sales notes, collected across the EU, are submitted by the buyer or the seller at the first sale of fish and show information on the freshness, presentation and size grade by species.

For the purpose of this exercise each fishing trip must be assigned to one of the selected fisheries. For each trip landings of cod, haddock, whiting, hake, monkfish, megrim and nephrops were assessed in terms of volume and value, with a grouping of other species summing up all other species landed from the trip. The economic value of cod plus haddock plus whiting composed the $\mathrm{CHW}$ value, the value of hake,

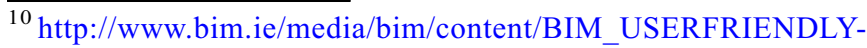
GUIDE_EU_LOGBOOK,SECTION,1.pdf.

${ }^{11} \mathrm{https} / / /$ ec.europa.eu/fisheries/cfp/control/technologies_en.
}

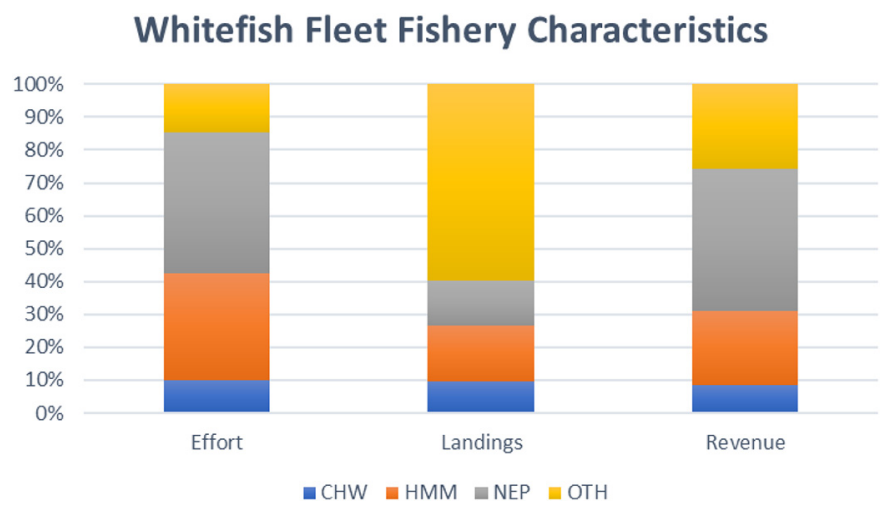

Fig. 3. Effort (days at sea), landings (tonnes) and revenue $(€)$ shares of the whitefish fleet by fishery (cod, haddock, whiting - CHW; hake, monkfish, megrim - HMM; nephrops - NEP; all others - OTH) in 2019.

monkfish and megrim composed the HMM value and the nephrops value composed the NEP value. All other species were summed to compose the OTH value. The trip was then allocated to the grouping of whichever of the four economic values was largest. For the set of all fisheries $F=\left\{f_{1}, \ldots f_{k}\right\}$ the determination of fishing trip into a fishery will follow;

Fishing $\operatorname{Trip}_{F}=\max \left\{\right.$ Value $_{f_{1}}$, Value $_{f_{2}}$, Value $_{f_{3}}, \ldots$, Value $\left._{f_{k}}\right\}$

where Fishing $\operatorname{Trip}_{F}$ is the fishery of the fishing trip, Value $f_{1}$ is the value of all fish landed within fishery 1 of the fishing trip, Value $_{f_{k}}$ is the value of all fish landed in fishery $\mathrm{k}$ of the fishing trip, and the fishery of maximum value determines Fishing $\operatorname{Trip}_{F}$.

This method follows the logic that fishers fish for value and not quantity of fish (Grafton et al., 2006; Hilborn et al., 2004). The data used in this exercise relate to the year 2019.

Basic statistics on activity of the fleet per fishery showing the distribution of effort, volume of landings and value of landing are shown in Table 1. With this information the disaggregation of costs to a fishery can begin.

Figure 3 presents the allocation for the whitefish fleet of total effort applied, total landings and total revenue within each of the four fisheries considered (cod-haddock-whiting CHW, hake-monkfish-megrim - HMM, nephrops - NEP and other - OTH). The NEP fishery is the most exploited accounting for around half of all effort, followed by the HMM fishery with around $25 \%$ of total effort. The remaining quarter of effort is shared between the CHW and OTH fisheries. In terms of landing volumes the OTH fishery dominates with 
Table 2. Number of vessels of the whitefish fleet exploiting each fishery including count of multiple fishery exploitation.

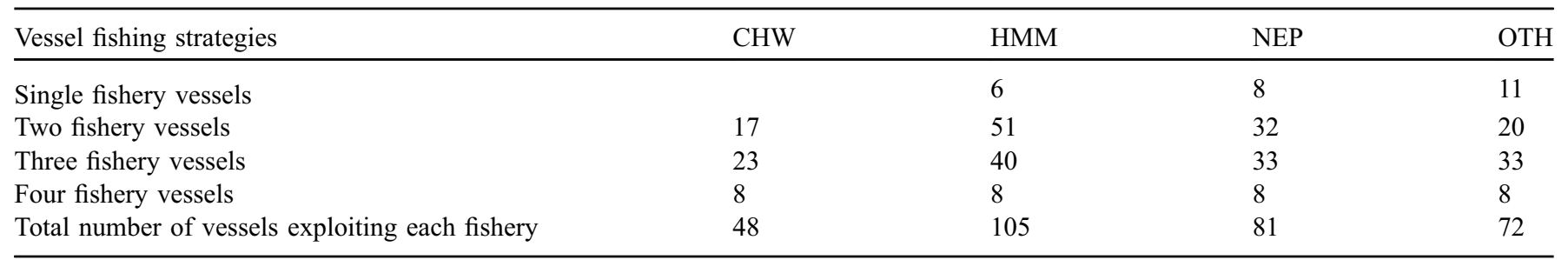

Fishery definition: (cod, haddock, whiting - CHW; hake, monkfish, megrim - HMM; nephrops - NEP; all others - OTH).
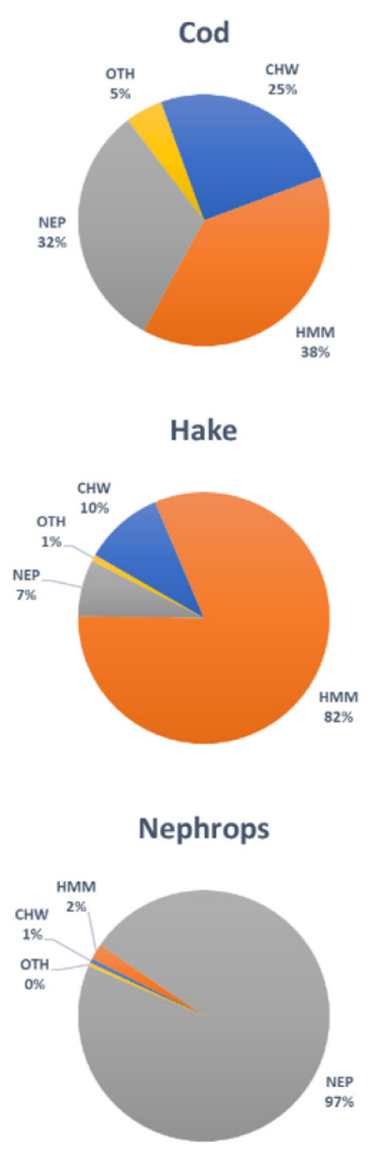
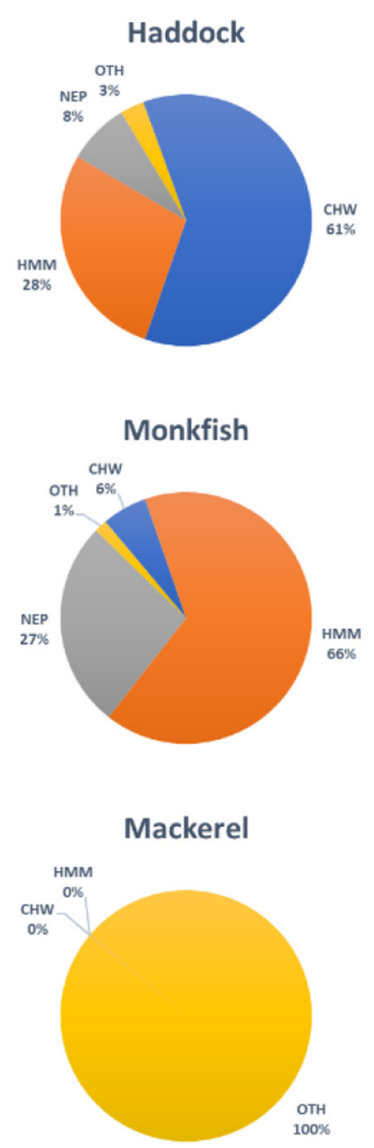
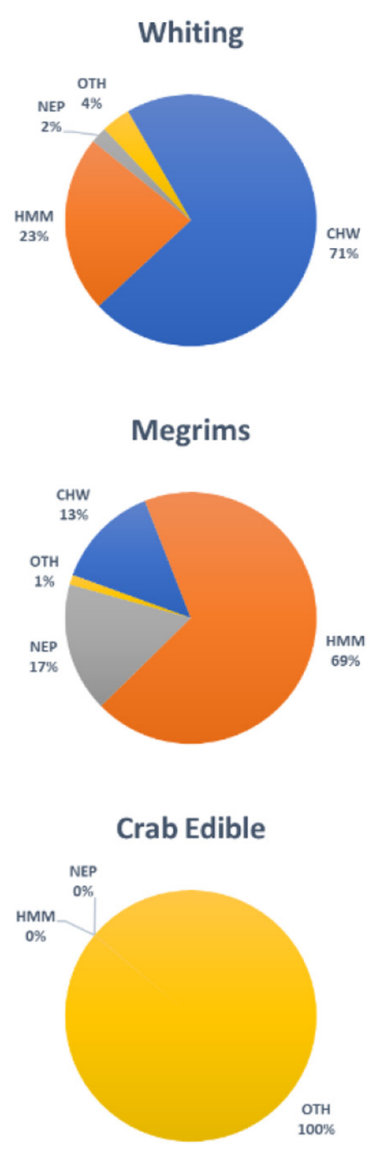

Fig. 4. Landing weights as a fraction of total tonnage landed of main species within each fishery (cod, haddock, whiting - CHW; hake, monkfish, megrim - HMM; nephrops - NEP; all others - OTH) in 2019.

$\sim 60 \%$ of the total with the remaining split between the CHW, HMM and NEP fisheries. The OTH landings are composed mainly of lower value pelagic species such as mackerel and herring and consequently the share of revenue is much lower than the landing share. Nevertheless, this OTH share of revenue is significant, especially when assessed against the share of effort. This is logical given that pelagic species require low levels of effort due to schooling effects (Paloheimo and Dickie, 1964) while prices have been increasing and so represent a profitable fishery to enter and can be an important component of fisher annual income. The CHW fishery shares are relatively equal across effort, landings and revenue. The revenue shares of NEP equate with its effort shares while the revenue share of HMM is lower than its effort shares.

Another complicating factor when analysing the whitefish fleet is how vessels can exploit more than one fishery. In
Table 2 and Figure 5 the number of vessels that exploit from one fishery to all four fisheries is shown. Different combinations of fisheries can be exploited between the four. It is most common that two fisheries are exploited by the 136 vessels active in this segment. No vessels only exploit the CHW fishery while eight vessels only exploit the NEP fishery. The HMM fishery is the most commonly exploited fishery.

The data available also enables analysis of the significance of the nine main species caught by the case study fleet segment as bycatch species in each of the four fisheries (Fig. 4).

The top row of Figure 4 shows the landing volumes of cod, haddock and whiting with each fishery. For haddock and whiting the majority of total landings weight are from the CHW fishery however cod is sourced from the three defined fisheries to significant degrees. This is problematic in terms of fisheries management as this species is a potential choke for 
Table 3. Hypothetical example of landing composition of a fishing trip.

\begin{tabular}{llllll}
\hline & Volume (Tonnes) & Value $(€)$ & Price $(€ / \mathrm{kg})$ & Volume share $(\%)$ & Value share $(\%)$ \\
\hline Hake & 3 & 7500 & 2.50 & $30 \%$ & $31 \%$ \\
Monkfish & 2 & 8000 & 4.00 & $20 \%$ & $33 \%$ \\
Megrim & 1 & 3500 & 3.50 & $10 \%$ & $15 \%$ \\
Others & 4 & 5000 & 1.25 & $40 \%$ & $21 \%$ \\
Total & 10 & 24000 & 2.40 & $100 \%$ & $100 \%$ \\
\hline
\end{tabular}

the whitefish fleet ${ }^{12}$. The second row shows landings of hake, monkfish and megrim across the defined fisheries. For all three species at least two thirds of total landings are from the HMM fishery with the remaining landings mainly caught in the NEP fishery. Finally, nephrops is nearly exclusively landed from the NEP fishery. Mackerel and crab are exclusively caught in the OTH fishery.

\section{Material and methods II: cost disaggregation}

Costs that change with effort applied are fuel costs $(F u C)$, other variable costs such as provisions or landing fees $(\mathrm{VaC})$, crew costs $(\mathrm{CrC}-$ crew costs assumed to increase with higher effort levels) and repair and maintenance costs $(R m C)$. Costs that do not change with effort are fixed $(F x C)$ and capital costs $(\mathrm{CaC})$. Two basic methods to assign costs will be discussed; the proportional weight method and the proportional value method.

One unit of effort in the fishery results in landings and sales of a number of species of varying quantities and sizes. Under the proportional weight method it is assumed that each species within the mix caught in the fishing nets cost the same to catch, therefore the cost per unit of effort in the fishery $\left(C P U E_{f}\right)$ should be divided by the proportional weights of landings of all the species. In Table 3 a hypothetical example of a fishing trip is shown whereby, if vessel A, fishing in fishery HMM, lands a total of 10 tonnes of whitefish today, of which 3 tonnes are hake, 2 tonnes are monkfish, 1 tonne is megrim and the remaining 4 tonnes are a mixture of other demersal species then the cost of the monkfish component would be $0.2 * C P U E_{H M M}$.

The proportional weight method is the simplest method to disaggregate the costs however it may not be the most accurate. Under the proportional value method fishers target certain species, based on their potential value, by adapting gears and travelling to specific fishing grounds. So, in the example above where costs are disaggregated based on proportional weights the fisher may be targeting megrim and monkfish due to their higher value, but in the process of capturing these they capture other species like hake, cod, haddock and other mixed demersal stocks of lower value. Therefore, the value generated from the landings in the above example in Table 3 could result

\footnotetext{
${ }^{12}$ Gear trials carried out by BIM aim to reduce the catches of whitefish in the nephrops fishery to prolong the exploitation within this fishery (Browne et al., 2018; Browne et al., 2018b, 2018a; Cosgrove et al., 2019; Guyader et al., 2013; McHugh et al., 2017, 2019; Tyndall et al., 2017).
}

in a total trip value of $€ 24000$. Proportionally monkfish composes $33 \%$ of the total value of the trip so under this method the cost of the monkfish component should reflect this economic driver, $0.33 * C P U E_{H M M}$.

Other aspects on board the vessel will contribute to differing costs per species such as handling and processing. Species can be gutted, headed, tailed, filleted and winged on board involving more labour. Of the two methods of disaggregating costs, by weight and by value, it seems that the extra costs involved in on-board processing of species is better represented by the value method as this processing adds value to the landed species, which is reflected in the prices received $^{13}$, hence this method applies a cost to this value adding process.

Annual fixed and capital costs are not affected by the level of effort applied by a vessel or fleet and hence are relatively independent of the fishery exploited. These costs are a part of the process of obtaining fish so should be incorporated in the evaluation of the economic performance of fishing segments. Just as higher on-board handling costs are likely to be justified by potential higher first sales prices, higher fixed and capital costs may be justified by the relatively higher revenues associated with participation in these fisheries.

The methodology to disaggregate costs to a species is now detailed using fuel costs as an example. To begin total annual costs are disaggregated by share of effort within each fishery. The formula for fuel cost by fishery is as follows:

$$
\mathrm{FuC}_{f}=\mathrm{FuC} * \text { Effort Share }_{f}
$$

where $\mathrm{FuC}_{f}$ is the total fuel costs per fishery $f, \mathrm{FuC}$ is the total annual fuel costs and Effort Share $f$ is the share of effort within fishery $f$, (which is calculated by division of the effort (in this case in days at sea) in fishery f by total effort in all fisheries).

Within the fishery this cost is further disaggregated by the economic value share of the selected species to the total value of the fishery. The fuel costs by species within a fishery is as follows:

$$
\mathrm{FuC}_{f s}=\mathrm{FuC}_{f} * \frac{\text { Value }_{f s}}{\text { Value }_{f}}
$$

where $\mathrm{FuC}_{f}$ is the total fuel costs of species $s$ within fishery $f$, $\mathrm{FuC}_{f}$ is the total fuel costs per fishery $f$, Value $\mathrm{f}_{f}$ is the total value in fishery $f$ and Value $f s$ is the total value of species $s$ in fishery $f$.

Total fuel costs of species $s$ within fishery $f$ is now divided by the weight of landings of the species in question. The fuel

\footnotetext{
${ }^{13}$ See Table A.4 in Appendix for variation in prices across fisheries.
} 


\section{Value Shares CHW Fishery}

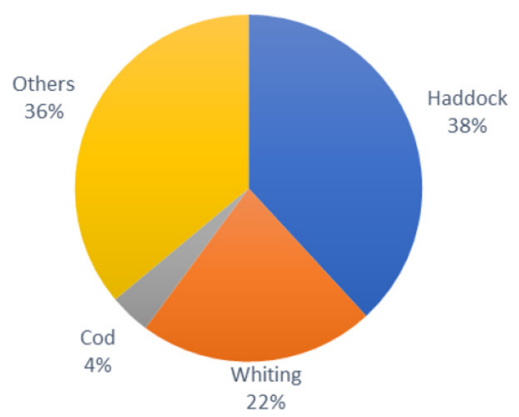

Value Shares NEP Fishery

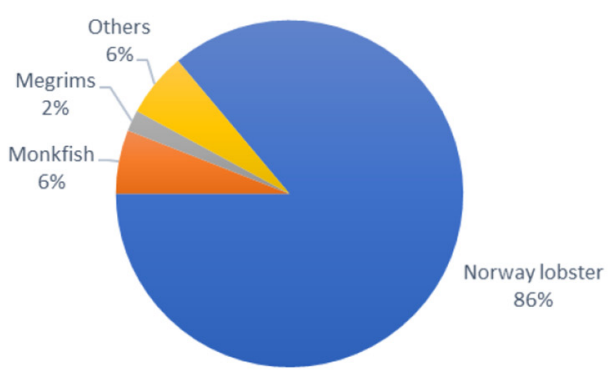

\section{Value Shares HMM Fishery}

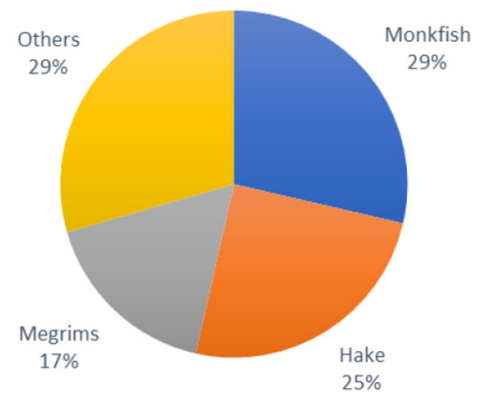

Value Shares OTH Fishery

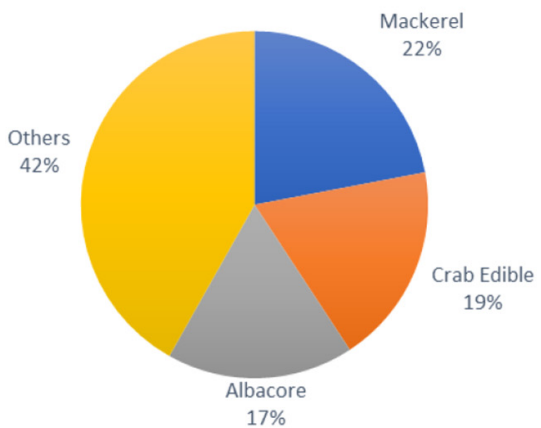

Fig. 5. Total landed value, in Euros, shares (\%) of main species landed by the whitefish fleet within each fishery (cod, haddock, whiting - CHW; hake, monkfish, megrim - HMM; nephrops - NEP; all others - OTH) in $2019^{14}$.

cost per unit of species within a fishery is as follows:

$$
\mathrm{FuCPU}_{f s}=\frac{\mathrm{FuC}_{f s}}{{\text { Landing } \mathrm{Weight}_{f s}}}
$$

where $\mathrm{FuCPU}_{f s}$ is the total fuel cost per unit of species $s$ in fishery $f, \mathrm{FuC}_{f s}$ is the total fuel costs of species $s$ within fishery $f$ and Landing Weight $f$ is the weight of landings of species $s$ within fishery $f$.

Finally, the total cost per unit of a species within a fishery can be calculated by following equations (1), (2), and (3) for all cost variables $\mathrm{FuC}, \mathrm{VaC}, \mathrm{CrC}, \mathrm{RmC}, \mathrm{Fx} C, \mathrm{CaC}$. The total cost per unit of species $s$ within fishery $f$ is then:

$$
\begin{aligned}
\mathrm{CPU}_{f s}= & \mathrm{FuCPU}_{f s}+\mathrm{VaCPU}_{f s}+\mathrm{CrCPU}_{f s} \\
& +\mathrm{RmCPU}_{f s}+\mathrm{FxCPU}_{f s}+\mathrm{CaCPU}_{f s}
\end{aligned}
$$

where $\mathrm{CPU}_{f s}$ is the total cost per unit of species $s$ in fishery $f$, $\mathrm{FuCPU}_{f s}$ is the total fuel cost per unit of species $s$ in fishery $f$, $\mathrm{VaCPU}_{f s}$ is the total variable cost per unit of species $s$ in fishery $f, \mathrm{CrCPU}_{f s}$ is the total crew cost per unit of species $s$ in fishery $f$, $\mathrm{RmCPU}_{f s}$ is the total repair and maintenance cost per unit of species $s$ in fishery $f$, FxCPU $\mathrm{F}_{f s}$ is the total fixed cost per unit of species $s$ in fishery $f$ and $\mathrm{CaCPU}_{f s}$ is the total capital cost per unit of species $s$ in fishery $f$.

\footnotetext{
${ }^{14}$ See Tables 3, A.1 and A.2 in Appendix for tables of volume, value and price for main species across fisheries.
}

This methodology has been applied to the Irish polyvalent general fleet $18 \mathrm{~m}+$ and the results are described in the following section.

\section{Results}

The Irish whitefish fleet works in mixed fisheries with diverse numbers of species caught and landed. The fisheries defined here are estimated using value shares and so do not preclude mixtures of other fishery stocks within the determined main fishing trip fishery, for instance cod or haddock in the HMM or NEP fisheries. To test the accuracy of the method in appropriately capturing these fisheries we will look at the species composition within each fishery in Figure 5.

The value of cod, haddock and whiting landed in trips assigned to the CHW fishery amount to $64 \%$ of the total value in this fishery. In landing weight terms this rises to $75 \%$. The value of hake, monkfish and megrim within the HMM fishery amounts to $71 \%$ of the total value ( $62 \%$ in landing weight). In the nephrops fishery $86 \%$ of the value is from nephrops $(69 \%$ in weight). Finally, in the OTH fishery the mackerel, crab and albacore fisheries compose $58 \%$ of the total value $(32 \%$ in weight). In general, these results are satisfactory, as at least two thirds of the three main fisheries (CHW, HMM, NEP) are composed of the target species, and hence signal that the methodology used here assigns fishing trips to an adequate degree. As can be seen in the Figure 5c monkfish and megrim are second and third most valuable stocks in the NEP fishery. 


\section{Cost per unit Landings CHW Fishery}

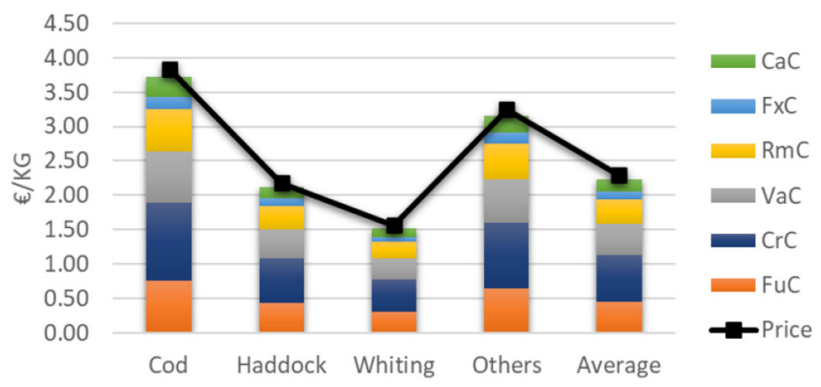

\section{Cost per unit Landings NEP Fishery}

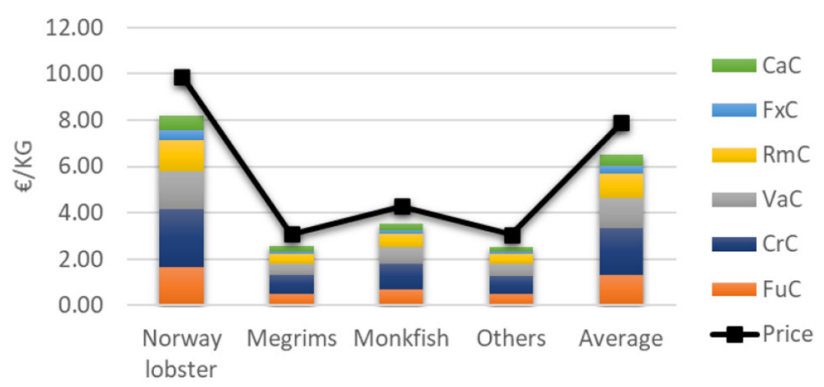

\section{Cost per unit Landings HMM Fishery}

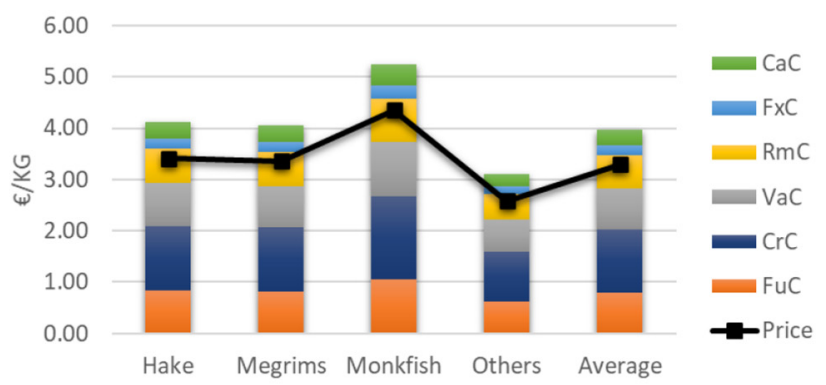

\section{Cost per unit Landings OTH Fishery}

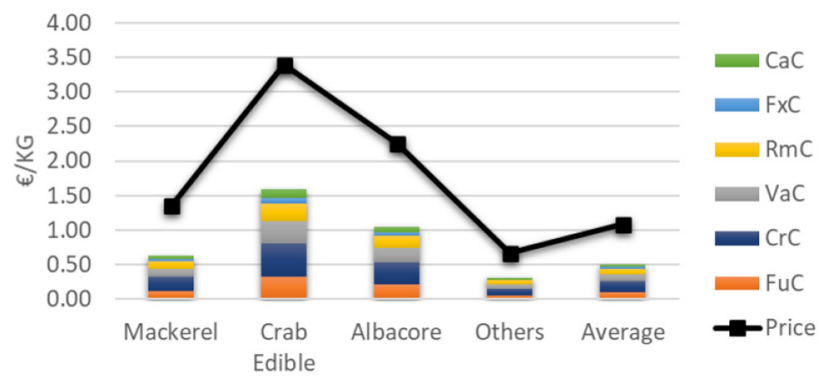

Fig. 6. Price and cost structure (fuel costs $(\mathrm{FuC})$, other variable costs $(\mathrm{VaC})$, crew costs $(\mathrm{CrC})$, repair and maintenance costs (RmC), fixed costs (FxC), capital costs $(\mathrm{CaC})$ ) of main fisheries (cod, haddock, whiting - CHW; hake, monkfish, megrim - HMM; nephrops - NEP; all others $\mathrm{OTH})$ and main species exploited by the whitefish fleet in $2019^{15}$.

Despite only composing $8 \%$ of the value and $16 \%$ of the landed weight from the NEP fishery this reflects the mixed nature of demersal fisheries.

In Figure 6 the costs are aggregated per unit of the main species within each fishery along with the average prices received. Each cost variable is shown in the bars to allow comparison of the first sales price per unit of landing against operational costs and total costs including fixed and capital costs. In three of the four fisheries the unit price received is higher than the sum of all costs. The only fishery where price does not surpass all costs is the HMM fishery. In this fishery the price fails to cover all of the operational costs.

Over half of the total costs for the whitefish fleet are composed of fuel costs and crew costs. In the CHW and the NEP fisheries the average prices are above the sum of the operational costs $(\mathrm{FuC}, \mathrm{CrC}, \mathrm{VaC}$ and $\mathrm{RmC})$ and the nonoperational costs ( $F x C$ and $\mathrm{CaC}$ ). In the HMM fishery prices do not cover operational costs at the unit level of the species and so this fishery generates the lowest returns to the fleet. The OTH fishery has the highest unit profitability with prices more than doubling total costs at the unit level.

In Figure 7 the average costs per unit of landings within each fishery and for all fisheries is shown for the whitefish fleet. In all fisheries but the HMM fishery the average costs are lower than the average price received per unit of fish. This results in profitable fishing activity by this fleet segment. As observed in the latest Annual Economic

\footnotetext{
${ }^{15}$ See Tables A.5, A.6, A.7 and A.8 in Appendix for corresponding values for each fishery.
}

\section{Cost per unit Landings All Fisheries}

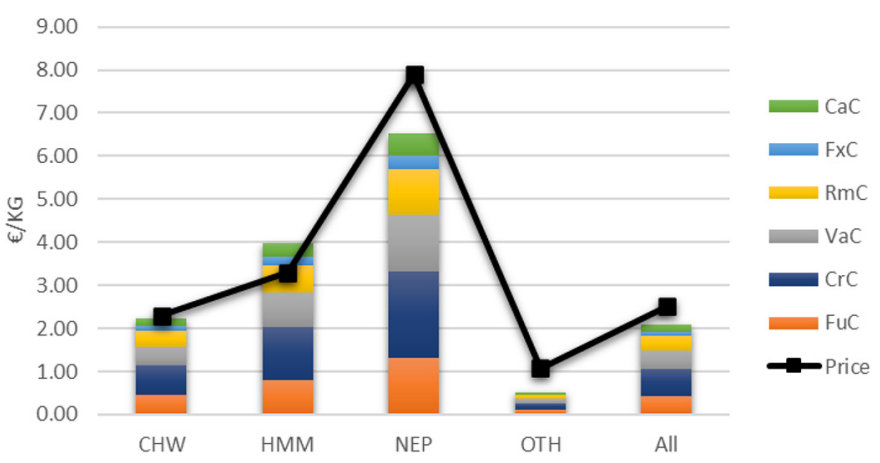

Fig. 7. Price and cost structure (fuel costs $(\mathrm{FuC})$, other variable costs $(\mathrm{VaC})$, crew costs $(\mathrm{CrC})$, repair and maintenance costs $(\mathrm{RmC})$, fixed costs (FxC), capital costs $(\mathrm{CaC})$ ) of each fishery (cod, haddock, whiting - CHW; hake, monkfish, megrim - HMM; nephrops NEP; all others - OTH) and for all fisheries exploited by the whitefish fleet in 2019.

Reports of European Fishing Fleets this fleet showed signs of overcapitalisation and unprofitable activity in the years before 2016 but has since generated annual net profits (STECF-20-06, 2020).

The main finding of this study is that, according to the methodology used here to disaggregate costs by fishery, the fishing activity in 2019 was also profitable in three of the main fisheries exploited by the whitefish fleet. The HMM fishery is the least profitable with average price received per 
unit covering the fuel, crew and variable costs but not completely covering repair and maintenance costs leading to a net loss per unit of fish landed. In the CHW and NEP fisheries all operational and non-operational costs are covered per unit landed. The unit profit margin in the OTH fishery can be seen to be the highest of all fisheries exploited by this fleet.

\section{Discussion and conclusion}

In this study a methodology has been described that allows estimation of the unit cost of fish species within mixed fisheries. The methodology has been applied to the Irish whitefish fleet (the polyvalent general fleet segments above $18 \mathrm{~m}$ in vessel length) and its activity in 2019 and the results show that the main fisheries exploited are profitable with one fishery generating unit losses. The price received surpasses the sum of all operational and non-operational costs signalling the capacity for this fleet segment to sustain activity in the longterm and an ability to reinvest profits into the renewal of the fleet. In this case, the margin is positive, in gross and net profit terms, for many important fishing stocks for the Irish whitefish fleet.

In three of the four fisheries categorised in this exercise the fleet demonstrates profitability with the average price received covering all costs. Only in the HMM fishery does the unit price not cover the fixed and capital costs. Despite unit losses in the HMM fishery overall the activity of the whitefish fleet is profitable and signals capacity to ensure long-term sustainability, generating resource rent that will allow the fleet to renew itself. The results here show that the OTH fishery is highly profitable given the low effort and significant value associated with it.

The methodology described in this paper allows estimation of the costs per unit of species across fisheries so the same species can present multiple catching cost structures depending on the fishery in which it is being harvested. In this exercise cod was shown to be largely caught across three fisheries. The average cost of capturing cod in each fishery ranged from $€ 3.03 / \mathrm{kg}$ in the NEP fishery to $€ 4.38 / \mathrm{kg}$ in the HMM fishery ( $€ 3.72 / \mathrm{kg}$ in CHW fishery and $€ 1.69 / \mathrm{kg}$ in the OTH fishery). This shows the basic difference between how much it costs to catch cod as a target and its cost as a bycatch in another targeted fishery. This can be used in fishing policy to determine the most efficient mean of managing multiple stocks in a mixed fishery context. In certain fisheries eliminating bycatch is very difficult therefore this analysis could determine whether certain quota stocks are more efficiently exploited as a bycatch in other fisheries rather than a targeted fishery of its own. In the contrary case, knowing these costs would allow accurate costbenefit analysis of implementing gear selectivity measures to reduce bycatch to favour targeted fisheries. This methodology could also be utilised to parametrise bio-economic models used to assess the potential impacts of alternative managements plans for these fisheries and that are used to assess total allowable catch changes and quota allocations (Curtin and Keatinge, 2018).

However, these calculations are heavily influenced by landings in contrast to catches. Quota constraints and the consequent discarding will have a very strong impact on these unitary costs as this segment may catch quantities of valuable fish in excess of the quantities they land but are forced to discard the difference due to lack of quota. If quota constraints did not exist it could thus be expected that costs per unit of species landed would fall. Additionally, following this methodology, if the fleet segment overall is unprofitable then average cost per unit must be above average price per unit. Therefore, the catch composition, particularly the main target species within each fishery, will influence the cost structure of the bycatch species in the same fishery. Other factors that may influence the unit costs include the definition of each fishery and the adequate scaling of the analysed fleet. In this application this latter aspect may play an important role as the Irish whitefish fleet has two main components; the freezer trawlers and the other vessels. The freezer trawlers are a group of vessels $(\sim 50)$ with freezing facilities on board the vessel that specialise on the nephrops fishery so their cost structure may vary from the whitefish fleet cost structure used in this analysis.

This analysis shows the results of the Irish whitefish fleet in 2019 and so is a static assessment of that year. It could be of benefit to include multiple years in the assessment to reflect the changing nature of fishing activity throughout time. Applying the method across multiple years would allow incorporation of the variations in price and costs and could potentially reveal insights into the dynamics at play in the exploitation of fisheries. The author is unaware of similar work that has been carried out in this line of research in the academic literature. Sandberg (2006) empirically examines how variable unit costs in Norwegian demersal and pelagic fisheries depend on output and the fish stock. Davie et al. (2014) define value per unit of effort in Irish mixed metier fisheries.

In terms of market analysis, this methodology allows the calculation of the margin that goes to the fishing sector at the first point of sale on the value chain on a species-by-species basis. This methodology could contribute to policy decisionmaking for fisheries managers in relation to issues relating to quota allocation and fleet management measures. Currently, several EU fleets are facing reduced quotas as a result of the UK's decision to leave the Union. Maximising the benefit of scarce quota and decisions of where (in terms of fisheries) this quota is exploited may become even more important. The socio-ecological implications of long-term planning of national fleets are considerable given the concentration of fleet segments in specific locations and the local supply chains that have developed over time. Optimising fleet structures can have direct, indirect, and induced effects at the local and regional levels and consequent effects on the ecological state of the fishery. Considering these variances in cost structures between fisheries may contribute to management plans and the development of incentives that will shape the future of national fleets.

Acknowledgments. This research did not receive any specific grant from funding agencies in the public, commercial, or notfor-profit sectors. The author accepts responsibility for all errors that may be contained in this paper. The author would like to thank the anonymous reviewers and the editor-in-chief for their very helpful comments and advice to improve this work. 


\section{References}

Boncoeur J, Coglan L, Gallic BL, Pascoe S. 2000. On the (ir) relevance of rates of return measures of economic performance to small boats. Fish Res 49: 105-115.

Browne D, Oliver M, McHugh M, Cosgrove R. 2018. Assessment of Dyneema ${ }^{\circledR}$ floating sweeps and fi sh scaring ropes in the Irish Sea Nephrops fishery (Issue February).

Browne D, Oliver M, McHugh M, Minto C, Cosgrove R. 2018a. Assessment of a SELTRA sorting box with $90 \mathrm{~mm}$ codend mesh size in the Irish Sea Nephrops fishery (Issue October).

Browne D, Oliver M, McHugh M, Minto C, Cosgrove R. 2018b. Assessment of an increase in codend mesh size and reduced codend circumference in an Irish Nephrops fishery (Issue May).

Carvalho N, Edwards-Jones G, Isidro E. 2011. Defining scale in fisheries: small versus large-scale fishing operations in the Azores. Fish Res 109: 360-369.

Cosgrove R, Browne D, Minto C, Tyndall P, Oliver M, Montgomerie M, McHugh M. 2019. A game of two halves: bycatch reduction in Nephrops mixed fisheries. Fish Res 210: 31-40.

Council of the European Union. 2009. Council Regulation (EC) No 1224/2009 of 20 November 2009 establishing a Community control system for ensuring compliance with the rules of the common fisheries policy, amending Regulations (EC) No 847/96, (EC) No 2371/2002, (EC) No 811/2004, (EC) No 768/2. Official Journal of the European Union, November 2009, 1-50.

Council of the European Union. 2017. REGULATION (EU) 2017/ 1004 OF THE EUROPEAN PARLIAMENT AND OF THE COUNCIL of 17 May 2017 on the establishment of a Union framework for the collection, management and use of data in the fisheries sector and support for scientific advice regarding the common. Officil Journal of the European Union, May 2014, 1-21.

Curtin R, Keatinge M. 2018. A methodology to measure the social impact of the EU quota setting procedure. Mar Policy 95: 248-255.

Daurès F, Trenkel VM, Guyader O. 2013. Modelling the fishing costs of French commercial vessels in the Bay of Biscay. Fish Res 146: $74-85$.

Davie S, Lordan C. 2009. Using a multivariate approach to define Irish métiers in the Irish Sea. Irish Fish Investigations 21: 49.

Davie S, Minto C, Officer R, Lordan C. 2014. Defining value per unit effort in mixed métier fisheries. Fish Res 165: 1-10.

Garza-Gil MD, Varela-Lafuente MM, Caballero-Miguez G, ÁlvarezDíaz M. 2011. Analysing the profitability of the Spanish fleet after the anchovy moratorium using bootstrap techniques. Ecol Econ 70: $1154-1161$.
Grafton RQ, Arnason R, Bjørndal T, Campbell D, Campbell HF, Clark CW, Connor R, Dupont DP, Hannesson R, Hilborn R, Kirkley JE, Kompas T, Lane DE, Munro GR, Pascoe S, Squires D, Steinshamn SI, Turris BR, Weninger Q. 2006. Incentive-based approaches to sustainable fisheries. Can J Fish Aquat Sci 63: 699-710.

Guillen J, Macher C, Merzéréaud M, Boncoeur J, Guyader O. 2015. Effects of the share remuneration system on fisheries management targets and rent distribution. Mar Resour Econ 30: 123-138.

Guyader O, Fahy E, Gaspar MB, Koutsikopoulos C, Alban F, Demanèche S, Eschbaum R, Reynal L, Maynou F, Tully O, Curtil O, Frangoudes K, Berthou P. 2013. Small scale fisheries in Europe: a comparative analysis based on a selection of case studies. Fish Res 140: 1-13.

Hilborn R. 2007. Managing fisheries is managing people: what has been learned. Fish Fish 8: 285-296.

Hilborn R, Punt AE, Orensanz J. 2004. Mote symposium invited paper beyond band-aids in fisheries management: fixing world fisheries. Management 74: 493-507.

McHugh M, Browne D, Oliver M, Tyndall P, Cosgrove R. 2017. Assessment of an inclined panel and flotation devices in the SELTRA (Issue November).

McHugh M, Oliver M, Browne D, Minto C, Cosgrove R. 2019. Benefits of $120 \mathrm{~mm}$ diamond and $100 \mathrm{~mm} \mathrm{T90}$ codends in the Celtic and Irish Seas (Issue February).

Paloheimo JE, Dickie LM. 1964. Abundance and fishing success. Rapports et Proces-Verbaux Des. Reunions, Conseil Permanent International Pour L'Exploration de La Mer 155: 152-163.

Prellezo R, Iriondo A. 2016. Measuring the economic efficiency of a crew share remuneration system: a case study of the Basque purse seiner-live bait fleet. Aquatic Living Resour 29: 106.

Sandberg P. 2006. Variable unit costs in an output-regulated industry: the fishery. Appl Econ 38: 1007-1018.

Simmonds EJ, Döring R, Daniel P, Angot V. 2011. The role of fisheries data in the development evaluation and impact assessment in support of European fisheries plans. ICES J Mar Sci 68: 1689-1698.

STECF-20-06. The 2020 Annual Economic Report on the EU Fishing Fleet, Publications Office of the European Union, Luxembourg, 2020, p. 432.

Tyndall P, Oliver M, Browne D, McHugh M, Minto C, Cosgrove R. 2017. The SELTRA sorting box: A highly selective gear for fish in the Irish Nephrops fishery (Issue February). http://www.bim.ie/ media/bim/content/publications/fisheries/6140-BIM-FisheriesConservation-report-4-1.pdf.

Cite this article as: Curtin R. 2021. Disaggregating species unit costs in mixed fisheries: the case of the Irish whitefish fleet. Aquat. Living Resour. 34: 14 


\section{Appendix A}

Table A.1. Landing statistics for hake and nephrops for the polyvalent general fleet segment $+18 \mathrm{~m}$ in 2019 .

\begin{tabular}{|c|c|c|c|c|c|}
\hline Segment & Vessel length & \multicolumn{2}{|c|}{ Hake } & \multicolumn{2}{|c|}{ Nephrops } \\
\hline Polyvalent general & VL1824 & 1771 & 5440447 & 3266 & 31163467 \\
\hline Polyvalent general & VL2440 & 1102 & 4023149 & 2299 & 23281580 \\
\hline Polyvalent general & VL1518 & 217 & 685970 & 289 & 1873465 \\
\hline Polyvalent general & VL1215 & 156 & 439206 & 104 & 926998 \\
\hline Total & & 3435 & 11133584 & 6027 & 57794767 \\
\hline
\end{tabular}

Table A.2. Total landings (tonnes) by the polyvalent general fleet segment $+18 \mathrm{~m}$ of the main species within each fishery (cod, haddock, whiting - CHW; hake monkfish megrim - HMM; nephrops - NEP; all others - OTH) in 2019.

\begin{tabular}{|c|c|c|c|c|c|}
\hline Landings (Tonnes) & CHW & HМM & NEP & ОTH & Total \\
\hline Cod & 123 & 191 & 157 & 24 & 496 \\
\hline Haddock & 2170 & 1003 & 283 & 109 & 3565 \\
\hline Hake & 296 & 2345 & 209 & 24 & 2873 \\
\hline Monkfish & 187 & 2116 & 857 & 52 & 3212 \\
\hline Megrims & 320 & 1629 & 395 & 30 & 2374 \\
\hline
\end{tabular}

Table A.3. Total landing value (Euros) by the polyvalent general fleet segment $+18 \mathrm{~m}$ of the main species within each fishery (cod, haddock, whiting - CHW; hake monkfish megrim - HMM; nephrops - NEP; all others - OTH) in 2019.

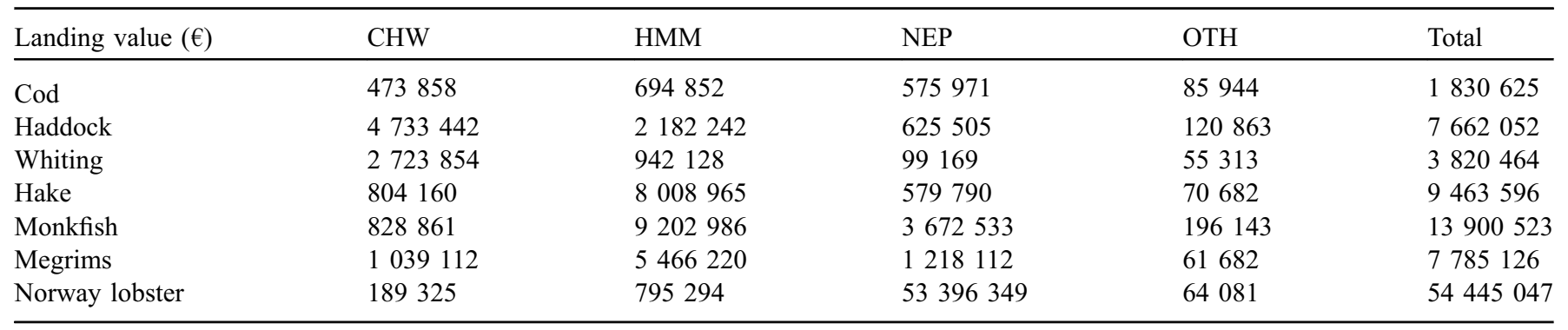

Table A.4. Average price $(€ / \mathrm{kg})$ by the polyvalent general fleet segment $+18 \mathrm{~m}$ of the main species within each fishery (cod, haddock, whiting CHW; hake monkfish megrim - HMM; nephrops - NEP; all others - OTH) in 2019.

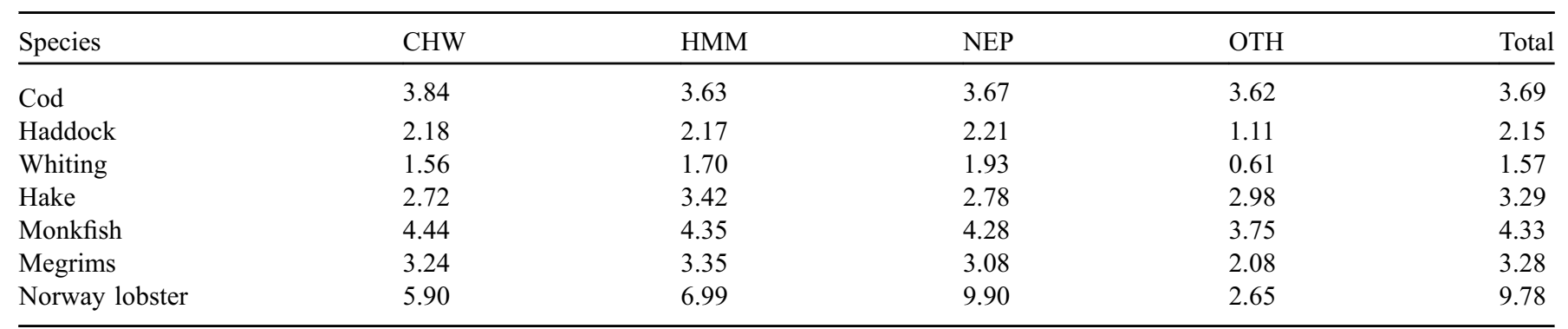


Table A.5. Price and cost structure (fuel costs (FuC), other variable costs (VaC), crew costs $(\mathrm{CrC})$, repair and maintenance costs $(\mathrm{RmC})$, fixed costs $(\mathrm{FxC})$, capital costs $(\mathrm{CaC})$ ) of main species exploited in the $\mathrm{CHW}$ fishery (cod, haddock, whiting) by the polyvalent general $+18 \mathrm{~m}$ fleet segment in 2019.

\begin{tabular}{lllllllr}
\hline Species & Price & FuC & VaC & RmC & FxC & CaC \\
\hline Cod & 3.84 & 0.75 & 0.75 & 0.61 & 0.18 & 0.29 & 0.10 \\
Haddock & 2.18 & 0.43 & 0.42 & 0.35 & 0.25 & 0.07 & 0.12 \\
Whiting & 1.56 & 0.31 & 0.30 & 0.52 & 0.15 & 0.25 \\
Others & 3.25 & 0.64 & 0.63 & 0.36 & 0.11 & 0.17 \\
Average & 2.29 & 0.45 & 0.45 & 0.97 & 0.68 \\
\hline
\end{tabular}

Table A.6. Price and cost structure (fuel costs $(\mathrm{FuC})$, other variable costs $(\mathrm{VaC})$, crew costs $(\mathrm{CrC})$, repair and maintenance costs $(\mathrm{RmC})$, fixed costs $(\mathrm{FxC})$, capital costs $(\mathrm{CaC})$ ) of main species exploited in the HMM fishery (hake, monkfish, megrim) by the polyvalent general $+18 \mathrm{~m}$ fleet segment in 2019.

\begin{tabular}{llllllll}
\hline Species & Price & FuC & VaC & RmC & FxC & CaC \\
\hline Hake & 3.42 & 0.83 & 0.83 & 0.67 & 0.20 & 0.32 & 0.20 \\
Megrims & 3.35 & 0.82 & 0.81 & 0.66 & 0.86 & 0.26 & 0.41 \\
Monkfish & 4.35 & 1.06 & 1.05 & 0.51 & 0.15 & 0.25 & 1.24 \\
Others & 2.58 & 0.63 & 0.62 & 0.65 & 0.19 & 0.31 \\
Average & 3.29 & 0.80 & 0.80 & 0.96 \\
\hline
\end{tabular}

Table A.7. Price and cost structure (fuel costs $(\mathrm{FuC})$, other variable costs $(\mathrm{VaC})$, crew costs $(\mathrm{CrC})$, repair and maintenance costs $(\mathrm{RmC})$, fixed costs $(\mathrm{FxC})$, capital costs $(\mathrm{CaC})$ ) of main species exploited in the NEP fishery (hake, monkfish, megrim) by the polyvalent general $+18 \mathrm{~m}$ fleet segment in 2019 .

\begin{tabular}{llllllll}
\hline Species & Price & FuC & VaC & RmC & FxC & CaC \\
\hline Norway lobster & 9.90 & 1.66 & 1.64 & 1.34 & 0.40 & 0.64 \\
Megrims & 3.08 & 0.52 & 0.51 & 0.42 & 0.12 & 0.20 \\
Monkfish & 4.28 & 0.72 & 0.71 & 0.58 & 0.17 & 0.28 & 0.78 \\
Others & 3.07 & 0.51 & 0.51 & 0.42 & 0.12 & 0.20 & 0.78 \\
Average & 7.89 & 1.32 & 1.31 & 1.07 & 0.32 & 0.51 \\
\hline
\end{tabular}

Table A.8. Price and cost structure (fuel costs $(\mathrm{FuC})$, other variable costs $(\mathrm{VaC})$, crew costs $(\mathrm{CrC})$, repair and maintenance costs $(\mathrm{RmC})$, fixed costs $(\mathrm{FxC})$, capital costs $(\mathrm{CaC})$ ) of main species exploited in the OTH fishery (others) by the polyvalent general $+18 \mathrm{~m}$ fleet segment in 2019 .

\begin{tabular}{lllllllr}
\hline Species & Price & FuC & VaC & RmC & FxC & CaC \\
\hline Mackerel & 1.35 & 0.13 & 0.13 & 0.10 & 0.03 & 0.05 & 0.19 \\
Crab edible & 3.40 & 0.32 & 0.32 & 0.26 & 0.08 & 0.12 \\
Albacore & 2.26 & 0.21 & 0.21 & 0.17 & 0.05 & 0.08 \\
Others & 0.67 & 0.06 & 0.06 & 0.05 & 0.02 & 0.02 & 0.32 \\
Average & 1.08 & 0.10 & 0.10 & 0.08 & 0.02 & 0.04 \\
\hline
\end{tabular}

Table A.9. Cost structure for 4 selected species of interest landed by the polyvalent general fleet segment $+18 \mathrm{~m}$ in 2019 .

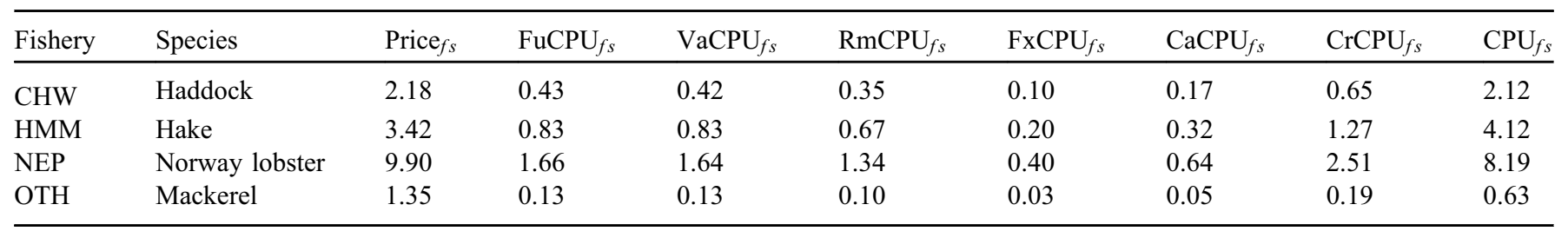

